\title{
The origin of Proterozoic massif-type anorthosites: evidence from interactions between crustal xenoliths and basaltic magma
}

\author{
T. J. DEMPSTER, R. J. PRESTON ${ }^{1}$ \& B. R. BELL \\ Division of Earth Sciences, Department of Geography, University of Glasgow, Glasgow G12 8QQ, United Kingdom \\ ${ }^{1}$ Present address: Department of Geology and Petroleum Geology, University of Aberdeen, Aberdeen AB24 4UE, \\ United Kingdom
}

\begin{abstract}
Plagioclase-rich reaction zones occur around numerous aluminous crustal xenoliths within a suite of Palaeogene sub-volcanic basic sheets on the Isle of Mull, NW Scotland. The xenoliths consist of a glassy core, containing mullite needles, generated from the melting of pelitic source rocks. Thick plagioclase mantles grew at the interface between the aluminous liquid and the enclosing basaltic magma and provide a high-level analogue for the petrogenesis of Proterozoic massif-type anorthosites. Similar interactions between mantle-derived basic magmas ponded at the base of the crust and relatively Al-rich lower crustal lithologies would result in the precipitation of large volumes of plagioclase. Anorthosite massifs were then emplaced at higher crustal levels as crystal-rich mushes within relatively juvenile Proterozoic crust. The model negates the need to crystallize large volumes of mafic minerals prior to the production of plagioclase-saturated liquids, and also accounts for the significant influence of crustal sources on the isotopic signatures of all members of the anorthosite suite.
\end{abstract}

Keywords: Proterozoic, anorthosite, geochemistry, plagioclase, xenoliths.

The formation of massif anorthosites, with large volumes of igneous plagioclase, has long puzzled petrologists. Principal amongst the problems has been the nature of the parental magma capable of producing such plagioclase-rich assemblages. In this study we report on a small-scale analogue for the formation of anorthosites from a suite of Palaeogene, high-level, xenolithic basaltic sheets on the Isle of Mull, NW Scotland. In these rocks, abundant plagioclase has crystallized at the interface between basaltic magma and aluminous xenoliths.

\section{Proterozoic massif-type anorthosites}

Massif-type anorthosites are an almost entirely Proterozoic phenomenon and appear to characterize a unique period in Earth history (Morse 1982; Ashwal 1993). Such anorthosites are thought to have been generated within rift environments (Bridgwater \& Windley 1973), and form very large, coarsegrained intrusive complexes, with individual plutons of batholithic proportions. The complexes typically include leuconorite, leucogabbro and leucotroctolite (e.g. Duchesne \& Demaiffe 1978; Xue \& Morse 1993). Plagioclase compositions vary between $\mathrm{An}_{40}$ and $\mathrm{An}_{60}$, are commonly Fe- and Ti-rich, and may contain exsolved ilmenite (Ashwal \& Wooden 1989). Al-rich orthopyroxene (commonly megacrystic) and olivine are common, the former probably indicative of crystallization at high pressures (Emslie 1980; Wiebe 1986). Clinopyroxene is rare, and large masses of mafic and ultramafic material are conspicuous by their absence, although many massifs do contain small mafic bodies (Ashwal 1982; Xue \& Morse 1993). K-rich plutonic rocks, from monzonite to granite, are typically also associated with anorthosite massifs (e.g. Duchesne \& Demaiffe 1978; Emslie \& Hegner 1993).

Many massif-type anorthosites preserve magmatic features such as ophitic textures and igneous layering, suggesting that liquid-crystal fractionation processes played an important role in their formation. However, the nature of the parental magmas is much debated, and a wide variety of compositions have been suggested (e.g. Bowen 1917; de Waard \& Romey 1969; Duchesne \& Demaiffe 1978). Many isotopic studies suggest that the parental magmas to anorthosites were derived from the mantle (e.g. Menuge 1988; Emslie \& Hegner 1993), although crustal contamination may also be significant (e.g. Ashwal et al. 1986). The Fe-rich nature of the mafic minerals within anorthosites requires that the initial parental magma, assuming it to be of mantle origin, fractionated considerably prior to the formation of the anorthosites. Dykes and sills of finer-grained ferrodiorite (jotunite) composition are ubiquitously associated with massif anorthosites. For example, in the Hidra Massif, Norway, the anorthosite grades into finegrained ferrodiorite at the margin, suggesting that the ferrodiorite was the parental magma (Demaiffe \& Hertogen 1981). However, other studies (Duchesne et al. 1989) have shown that ferrodiorites cannot be comagmatic with the anorthosites and may represent lower crustal anatectic melts on the basis of their high initial $\mathrm{Sr}$ isotope ratios relative to the anorthosites.

The present consensus for the petrogenesis of massif-type anorthosites is that tholeiitic magmas ponded, and fractionated mafic phases at the base of the crust during rifting (Emslie 1980). Liquids became plagioclase-supersaturated, the plagioclase accumulated, and rose diapirically to higher crustal levels. Ferrodiorite bodies are often considered coeval but not comagmatic to the anorthosites, with separate sources being implied, either mantle or lower crustal, and associated granitic rocks most likely represent the products of deep crustal anatexis (Rämö \& Haapala 1995). However, some features of the anorthosites are difficult to relate to extensive fractional crystallization of basaltic magmas at the base of the crust. Plagioclase crystals typically lack zoning (e.g. Ashwal \& Wooden 1989), and individual plutons often show a limited range of plagioclase compositions (e.g. Duchesne \& Demaiffe 


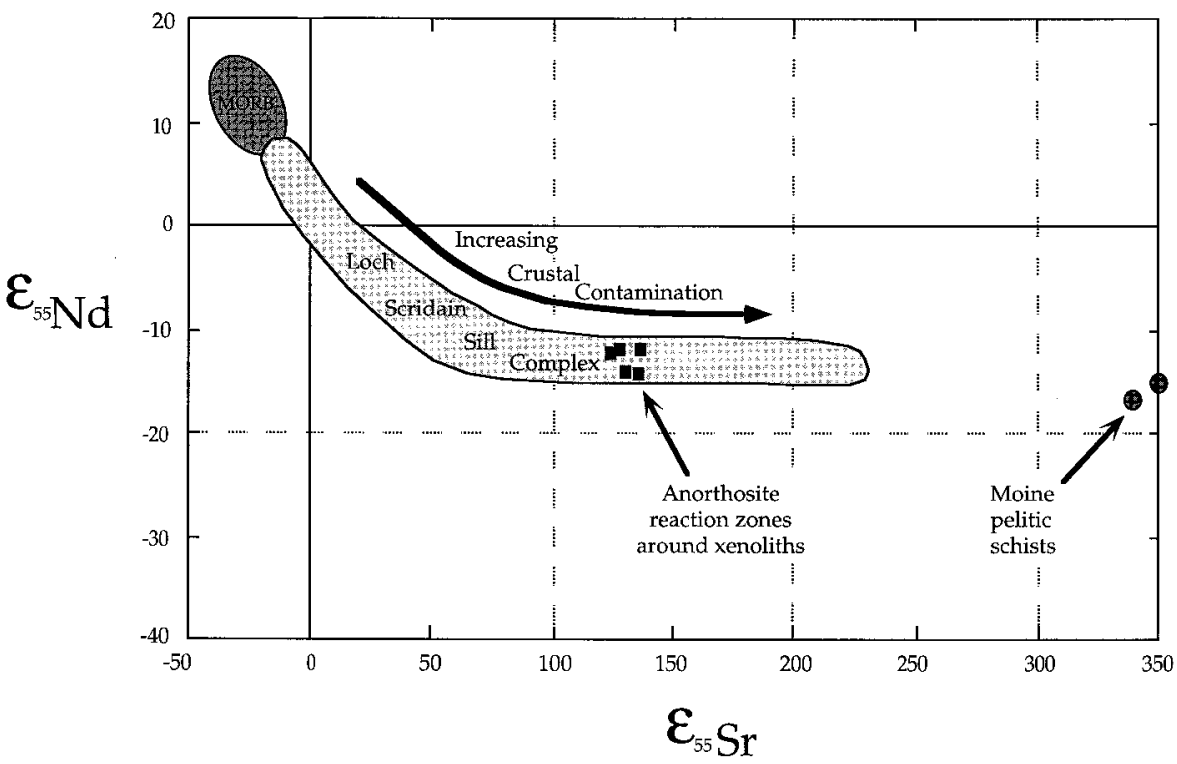

Fig. 1. $\varepsilon_{55} \mathrm{Sr} v . \varepsilon_{55} \mathrm{Nd}$ isotope diagram showing initial isotopic compositions of plagioclase rims to the mullite-bearing aluminous xenoliths. Contamination trend within the Loch Scridain Sill Complex is towards the metasedimentary pelites of the local Moine succession (Preston et al. 1998, in press).

1978). Despite the entrainment of a few high pressure orthopyroxene megacrysts, there is no evidence of voluminous ultramafic cumulates within the crust, although these could sink back into the mantle (Ashwal 1993). In addition to these factors, estimates of the bulk composition of parental magmas to anorthosites indicate a lack of the normative diopside component, which is typically associated with mantle-derived melts.

\section{Plagioclase rims to aluminous crustal xenoliths}

A suite of high-level, xenolithic minor intrusions have been emplaced into the Palaeogene lava field and underlying Mesozoic sedimentary and Late Proterozoic (Moine Group) metasedimentary rocks around Loch Scridain $\left(56.18^{\circ} \mathrm{N}\right.$ $\left.6.1^{\circ} \mathrm{W}\right)$, Isle of Mull, Scotland. The compositions of the sheets range from basaltic tholeiites to rhyolites and many of the more basic members carry a variety of xenoliths, predominantly derived from quartzites and aluminous pelites of the Moine Group (Thomas 1922; Thompson et al. 1986). The geochemistry of the Loch Scridain minor intrusions is described in detail by Preston et al. (1998) and the petrology of the xenolith suite and their role in crustal contamination of the basaltic magmas is documented by Preston et al. (in press). In this paper we briefly summarize some of the key features from these two studies most relevant to the generation and evolution of the aluminous crustal xenoliths.

The Loch Scridain Sill Complex exhibits a wide range of isotopic compositions (Fig. 1) and the rhyolitic members of the suite are thought to be largely derived from partial melting of pelites within the Moine Group (Preston et al. 1998). The basic magmas evolved through a process of combined fractional crystallization and crustal assimilation, resulting in a range of isotopic signatures $\left({ }^{87} \mathrm{Sr} /{ }^{86} \mathrm{Sr}_{\mathrm{i}}=0.703-0.714 ;{ }^{143} \mathrm{Nd} /{ }^{144} \mathrm{Nd}_{\mathrm{i}}=\right.$ $0.5129-0.5118$ ). The aluminous xenoliths are typically rounded masses (up to $60 \mathrm{~cm}$ across), although large rafts several metres across have been found. The most common variety consists of a core of glass (buchite) (with $\mathrm{Al}_{2} \mathrm{O}_{3}$ up to $30 \mathrm{wt} \%$; Table 1) containing 10-30\% mullite needles $(50 \times 2 \mu \mathrm{m})$, surrounded by a thick (up to $20 \mathrm{~cm}$ ) coarsely crystalline rim of calcicplagioclase (Fig. 2a) (Thomas 1922), which may account for $>80 \%$ of the xenolith. The bulk of the rim plagioclase has a
Table 1. Average composition of mullite-bearing buchites

\begin{tabular}{lrl}
\hline & $x$ & $\sigma$ \\
\hline $\mathrm{SiO}_{2}$ & 53.0 & 5.3 \\
$\mathrm{TiO}_{2}$ & 2.1 & 0.5 \\
$\mathrm{Al}_{2} \mathrm{O}_{3}$ & 28.5 & 2.7 \\
$\mathrm{Fe}_{2} \mathrm{O}_{3}$ & 2.1 & 1.8 \\
$\mathrm{MnO}$ & 0.0 & 0.0 \\
$\mathrm{MgO}$ & 0.8 & 0.8 \\
$\mathrm{CaO}$ & 0.6 & 0.2 \\
$\mathrm{Na}$ & 2.0 & 0.9 \\
$\mathrm{~K}_{2} \mathrm{O}$ & 3.0 & 2.1 \\
$\mathrm{P}_{2} \mathrm{O}_{5}$ & 0.1 & 0.1 \\
Total & 92.3 & 2.0 \\
LOI & 5.9 & 1.6 \\
& &
\end{tabular}

Based on XRF analyses quoted in Preston et al. (1998). All $\mathrm{Fe}$ as $\mathrm{Fe}_{2} \mathrm{O}_{3}$.

composition between $\mathrm{An}_{55}$ and $\mathrm{An}_{65}$, the most calcic of which is similar to that of plagioclase phenocrysts in the host basalt (c. $\left.\mathrm{An}_{64}\right)$ (Preston et al. in press). The plagioclase within the rim generally forms equant $2-5 \mathrm{~mm}$ laths, and is typically Ti-rich (up to $1400 \mathrm{ppm}$ ), with numerous mineral inclusions (Preston et al. in press). Towards the buchite core, inclusions of mullite are common, along with large $(c .1 \mathrm{~mm})$ commonly skeletal corundum. Inclusions of aluminous spinel are more abundant towards the host basalt contact (Fig. 2a), where the plagioclase is typically oscillatory zoned. Calcic plagioclase (up to $\left.A n_{87}\right)$ also occurs within the rim and is considered to have formed during subsequent melting, or from reaction between spinel and the aluminous liquid (Preston et al. in press). Trapped within the rim of plagioclase are pockets of quenched basaltic melt (Fig. 2a) with microlites of plagioclase and either ferroaugite (near to the basalt contact) or ferropigeonite (near to the contact with the buchite). Initial isotope ratios of plagioclase from the rims $\left({ }^{87} \mathrm{Sr} /{ }^{86} \mathrm{Sr}_{\mathrm{i}} \approx 0.714 ;{ }^{143} \mathrm{Nd} /\right.$ ${ }^{144} \mathrm{Nd}_{\mathrm{i}} \approx 0.5119$ ) point to the involvement of upper crustal lithologies such as the Moine pelitic schists, in the generation of the aluminous xenoliths (Fig. 1) (Preston et al. in press). Mullite buchites without plagioclase rims are also found, and 
a) Anorthosite reaction zone between crustal xenolith and basalt

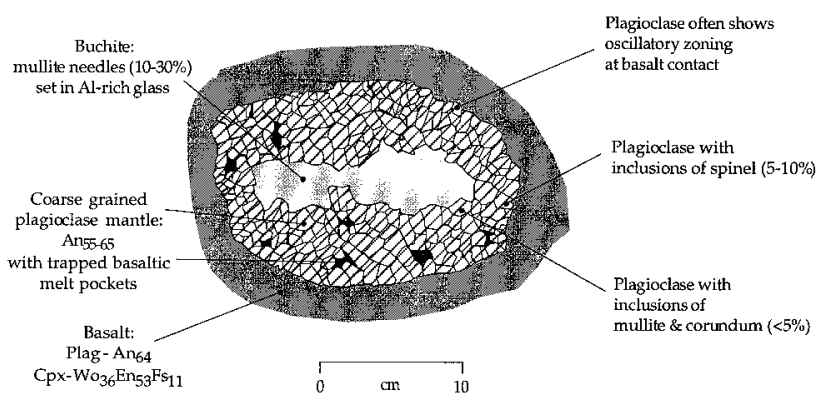

b) Anorthosite reaction zone between lower crust and basalt

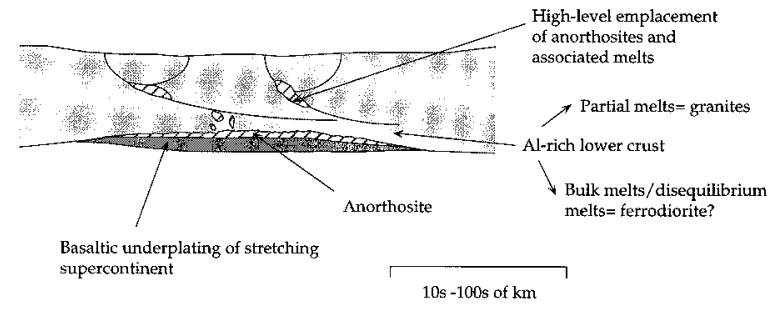

Fig. 2. Schematic diagrams showing: (a) The mineralogical characteristics of a typical aluminous xenolith within a Palaeogene basaltic sheet, Isle of Mull. Typical modal proportions of aluminous mineral phases within both the glassy core and plagioclase rim are given; (b) The formation of Proterozoic massif-type anorthosites at the base of the crust during underplating by basaltic magma.

are thought to have lost their rims during final emplacement. However, where preserved intact, the xenoliths retain a concentric structure (Fig. 2a), and the textures indicate that the thick plagioclase rims have extracted components from both the aluminous melt and the basaltic magma. The following model documents the formation of the aluminous xenoliths (Preston et al. in press), and involves processes which occurred concurrently with the extraction of low-temperature equilibrium silicic melts (now represented by rhyolite sheets) from other parts of the pelitic basement:

(a) Disequilibrium incongruent melting reactions within muscovite-rich pelites generate an aluminous liquid and mullite (cf. Brearley \& Rubie 1990). At the same time, voluminous plagioclase $\left(\mathrm{An}_{55-65}\right) \pm$ corundum crystallizes at the interface between the basic magma and the aluminous liquid. The heat required to drive the melting reactions is supplied by the crystallization of plagioclase (cf. Bowen 1922).

(b) Subsequent percolation of basaltic melts into, and reaction with, the newly-formed plagioclase rim, causes some melting of the plagioclase, and mixing with aluminous melt results in crystallization of spinel and more plagioclase.

(c) Fragmentation of xenoliths during high-level emplacement.

Plagioclase reaction rims around solid xenoliths or xenocrysts are relatively common. Bowen (1922) was the first to argue that the reaction of an aluminous xenolith with a basic magma would cause excess precipitation of plagioclase from the magma, and crystallization of orthopyroxene, at the expense of clinopyroxene. Van Bergen \& Barton (1984) describe various plagioclase-rich concentric zones around aluminous xenoliths in silicic lavas that are thought to have resulted from diffusive interaction with the enclosing magma. The experiments of Wark \& Stimac (1992), in which K-feldspar crystals were suspended in a basic melt, resulted in the growth of plagioclase mantles around K-feldspar, and shed light on the formation of some rapakivi-textured granites. Thus, plagioclase mantles may be a common result of mixingreaction processes in magmas.

There is little to indicate that the thermal conditions were unusual during these xenolith-magma interactions and hence processes involved in such interactions between basaltic liquids and upper crust are potentially common. Consequently, similar, although perhaps more extensive, interactions with basaltic magmas are also predicted in the lower crust. At elevated pressures, such reaction products are also likely to be dominated by plagioclase (although probably of a more sodiccomposition (Green \& Ringwood 1967)), together with aluminous orthopyroxene, rather than the plagioclase and spinel-bearing assemblages in the high-level Loch Scridain xenoliths.

\section{Anorthosite formation during interaction between lower crust and basaltic magma}

Proposals that massif-type anorthosites represent crustal anatectic residues (e.g. Berg 1968; Frith \& Currie 1976) have not been widely accepted, due to their coarse-grained igneous textures, the isotopic and geochemical evidence in support of a mantle source, and the evidence for shallow emplacement (Ashwal 1993). Taylor et al. (1984) suggested that magmas of suitably Al-rich composition could be generated from the lower crust after extraction of granitic melts, thus depleting the lower crust in $\mathrm{K}, \mathrm{Rb}, \mathrm{U}$ and $\mathrm{Th}$, and enriching the residue in $\mathrm{Al}, \mathrm{Sr}$ and $\mathrm{Eu}$. Hence, in their model, anorthosite magmas are derived through direct anatexis of the Al-enriched residues, and the mafic component of anorthosite massifs is considered to be generated from the more mafic portions of the lower crust. However, it is necessary to infer the involvement of a mantle plume to provide the heat for melting the Al-rich residue (Taylor et al. 1984), which would undoubtedly also supply large volumes of basaltic magma to the base of the crust.

Various workers have followed Bowen (1922) and proposed that assimilation of crustal lithologies by basaltic magmas resulted in the generation of plagioclase-rich magmas. Thus, Michot (1964) suggested that anorthosites were derived by the assimilation of pelitic sediments within a basaltic host, and Philpotts (1968) proposed mixing of mantle-derived basaltic magmas with granitic melts to enhance crystallization of plagioclase. The crustal xenoliths within the Loch Scridain basaltic sheets demonstrate that relatively large volumes of coarsely crystalline plagioclase can be precipitated through reaction between small Al-rich crustal xenoliths (originally pelitic metasedimentary rocks, Thomas 1922) and basaltic magmas (Fig. 2a). These Palaeogene xenoliths provide a potential analogue for the processes which occurred during Proterozoic underplating of the crust by basaltic magmas (Fig. 2b). Obviously, pelitic crust of the sort present in Mull is unlikely to have formed a significant component of the lower crust during the Proterozoic; however, relatively Al-rich crustal lithologies may have been present in a variety of forms in the felsic-intermediate lower crust, such as residues, after granitic melts have been removed (e.g. Taylor et al. 1984). Crustal xenoliths consisting of plagioclase + orthopyroxene \pm spinel assemblages have been widely reported (e.g. Vielzeuf 
1983; Graham 1987), and have been considered to represent the granulite facies gneisses from which granitic melts have been removed. Plagioclase (up to $\mathrm{An}_{55}$ ) may dominate these assemblages, and the orthopyroxene may have a sub-ophitic relationship to the plagioclase (Graham 1987).

Many problems of the petrology and geochemistry associated with massif-type anorthosites arise from arguments about the relative involvement of mantle and crustal reservoirs. We believe many characteristics of anorthosites can be explained if the basaltic magmas ponded at the base of the crust interact with a relatively aluminous lower crust. In our model, anorthosites represent the reaction products formed at the interface between these reservoirs. Plagioclase may dominate the early crystallization of basalts at pressures appropriate for the base of the crust, between 5 and 10 kbar (Thompson 1972), and at elevated pressure, orthopyroxene, rather than clinopyroxene, would be the mafic phase to crystallize (Green \& Ringwood 1967). Interaction between an aluminous crust and a basaltic magma will cause excess crystallization of plagioclase from the magma (Bowen 1922). The evidence from the crustal xenoliths found in the Loch Scridain high-level basaltic sheets shows that aluminous lithologies can be completely melted and, in such circumstances, a significantly larger amount of plagioclase would be likely to crystallize at the interface between the two liquids (Fig. 2a). The crystallization of plagioclase by reaction between aluminous melts and adjacent basaltic magma can account for both the large volumes and the relatively uniform compositions of plagioclase cumulates seen in individual massif-type anorthosites, as plagioclase compositions are buffered between these two reservoirs. More variable plagioclase compositions would be expected where there has been less interaction with the crust, and also greater proportions of augite within the anorthosite (cf. Morse 1979). It is also of note that where orthopyroxene dominates the mafic mineralogy of the anorthosite the intrusions tend to have a more 'crustal' isotopic signature and contain plagioclase of a more sodic composition, than the olivine-bearing anorthosites (Emslie 1985). Hence, the chemistry and mineralogy of anorthosites may reflect the degree of mixing between the crust and mantle reservoirs. Although the crust may act as a density filter for anorthosites (Morse 1982), and limit the emplacement of more Ca-rich intrusions, plagioclase within anorthosites is typically much less calcic than that which would crystallize from unmodified basaltic magmas. However, the Archaean crust was typically characterized by more Na-rich compositions, i.e. the high-Al tonalitetrondhjemite suite (Engel et al. 1974), than younger crust. Thus, the relatively sodic plagioclase present within the anorthosites may also reflect a significant contribution from such lower crustal sources. The Ti-enrichment of members of the anorthosite suite and high $\mathrm{Fe} / \mathrm{Mg}$ ratios of mafic minerals of the anorthosites may also in part be explained by a relatively large input from the lower crustal rocks. Hence, the model negates the need for extensive crystal fractionation prior to the formation of the anorthosite, and explains the lack of mafic cumulates. The $\mathrm{Sr}$ and $\mathrm{Nd}$ isotopic compositions of massiftype anorthosites would also be expected to display a mixed mantle-crust signature; however, most are emplaced into, and probably generated near, relatively juvenile late Archaean or Proterozoic crust and thus will be dominated by mantle-like isotopic signatures. Additionally, if part of the lower crust becomes molten whilst in contact with the ponded basaltic magmas, isotopic (and trace-element) equilibration between these two reservoirs is a distinct possibility.

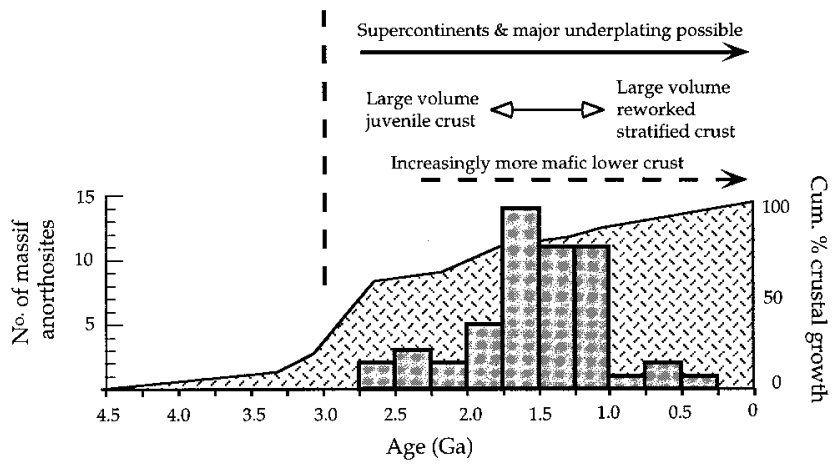

Fig. 3. Diagram illustrating the relationship between the number of massif-type anorthosites (histogram, using age data compiled by Ashwal 1993) and a curve showing cumulative growth of crust through time (after Taylor \& McLennan 1996). Initiation of massif-type anorthosite formation coincides with the time of major crustal growth.

A variety of lower crustal lithologies would be capable of reacting with basaltic magmas to generate anorthosites in the reaction zone (Fig. 2b), and some melting of lower crust seems an inevitable consequence of major underplating at depth. However, the associated monzonite/granite suite is characteristically emplaced later than the anorthosites (Ashwal 1993) and seems more likely to be generated during the final ascent of the feldspathic mushes. If the lower crust is melted during the underplating, the heat required to produce such melts would be in part balanced by the heat released by crystallization of the large volume of plagioclase (cf. Bowen 1922) in the anorthosite reaction zone. However, it would be predicted that such crustal melts should form a significant part of the anorthosite suite. The enigmatic ferrodiorites (jotunites) seem the most likely candidate for lower crustal melts (Duchesne et al. 1989). Some studies have noted a transition from ferrodiorites into anorthosites (Philpotts 1981) which may represent part of the original reaction zone, although typically such relationships will be severely disrupted during ascent. Geochemical similarities with the anorthosites have also led to the ferrodiorites being suggested as parental magmas to the anorthosites (Duchesne \& Demaiffe 1978) or residual liquids from anorthosite crystallization (Morse 1982). In the model presented here, anorthosites crystallize at the interface between mantle-derived basalts and either lower crust, or the ferrodiorite melts derived from the lower crust.

\section{Discussion}

The restriction of massif-type anorthosites to the Proterozoic has been the cause of much debate. Although our model requires that significant volumes of basaltic magma are ponded at the base of the crust, the lower crust plays an equally important role in the genesis of anorthosites. Thus, it may be the nature of the continental crust during the Proterozoic that restricted anorthosite occurrences to this eon. The majority of the Earth's crust (50-70\%) was formed towards the end of the Archaean, with a major period of growth between $c .3 .0$ and 2.5 Ga (Fig. 3) (Taylor \& McLennan 1996), which may have allowed formation of the first supercontinent during the Proterozoic (Hofmann 1989). This supercontinent would have had a thermal 'blanketing' effect on the underlying mantle, 
promoting large-scale upwellings, rifting and extensive production of basaltic magmas (Hofmann 1989) which could then underplate and interact with the crust. Anorthosites were formed by reaction between the lower crust and these basaltic magmas, and the anorthosites subsequently arose as crystal mushes to higher levels in the crust, generating granitic melts in the adjacent country rocks. Anorthosites are typically emplaced into relatively juvenile crust which may have experienced little by way of prior crustal reworking. During the Proterozoic, the crust became increasingly differentiated into a more felsic, less dense, upper crust and a relatively mafic lower crust (Taylor \& McLennan 1985). The crust also acquired a more granitic composition (higher $\mathrm{K} / \mathrm{Na}$ ) in contrast to the tonalite-trondhjemite crust that typifies the Archaean. Such factors may combine to dictate that towards the end of the Proterozoic (Fig. 3), basaltic melts had less opportunity to react with a relatively felsic, $\mathrm{Al}$ - and Na-rich lower crust, and hence to form anorthosites. Thus, it is the interaction between underplated basaltic magmas and juvenile undifferentiated lower crustal rocks during the Proterozoic which may hold the key to the anorthosite 'problem'. The general occurrence of anorthosites within belts (Herz 1969) may consequently be influenced by at least two factors: (a) the tectonics responsible for the generation of the basaltic magmatism and (b) the composition and nature of the lower crustal rocks with which these magmas react.

The Loch Scridain xenoliths preserve unique evidence of upper crustal contamination due primarily to the ponding of the basaltic magmas within high-level sheets. This contrasts with more turbulent plumbing systems where the detailed record of the interaction between crustal melts and basic magmas will be destroyed. At lower crustal levels more extensive evidence of interaction would be predicted as basaltic magmas would not lose heat efficiently. We propose that Proterozoic anorthosites were also formed during interaction between ponded basaltic magma and crustal lithologies, although the scale and location of the interaction was very different from those of the high-level xenoliths. However, the evidence from the Palaeogene Loch Scridian xenoliths suggests that the conditions necessary to generate anorthosites may occasionally pertain in the Phanerozoic Earth (i.e. underplating and juvenile crust), although a number of factors suggest that both generation and high-level emplacement of large anorthosite intrusions are becoming less likely through geological time.

Discussions with G. Rogers, R. Ellam and R. Muir are much appreciated, as is funding from the NERC. L. Ashwal and B. Upton are thanked for their constructive reviews of the manuscript.

\section{References}

Ashwal, L.D. 1982. Mineralogy of mafic and Fe-Ti oxide-rich differentiates of the Marcy anorthosite massif, Adirondacks, New York. American Mineralogist, 67, 14-27.

1993. Anorthosites. Springer-Verlag, London.

— \& Wooden, J.L. 1989. River Valley pluton, Ontario: a late-Archean/earlyProterozoic anorthosite intrusion in the Grenville Province. Geochimica et Cosmochimica Acta, 53, 633-641.

- — \& Emslie, R.F. 1986. $\mathrm{Sr}, \mathrm{Nd}$, and $\mathrm{Pb}$ isotopes in Proterozoic intrusives astride the Grenville Front in Labrador: implications for crustal contamination and basement mapping. Geochimica et Cosmochimica Acta, 50, 2571-2585.

Berg, R.B. 1968. Petrology of anorthosites of the Bitterroot Range, Montana. In: ISACHSEN, Y.W. (ed.) Origin of anorthosite and related rocks. Report of the New York State Museum Science Service, 19, 387-398.
Bowen, N.L. 1917. The problem of the anorthosites. Journal of Geology, 25, 209-243.

1922. The behaviour of inclusions in igneous magmas. Journal of Geology, 30, 513-570.

Brearley, A.J. \& RubIE, D.C. 1990. Effects of $\mathrm{H}_{2} \mathrm{O}$ on the disequilibrium breakdown of muscovite+ quartz. Journal of Petrology, 31, 925-956.

BRIDGWATER, D.D. \& WindLey, B.F. 1973. Anorthosites, post-orogenic granites, acid volcanic rocks and crustal development in the North Atlantic Shield during the Mid-Proterozoic. In: LisTer, L.A. (ed) Symposium on granites, gneisses and related rocks. Geological Society of South Africa Special Publication, 3, 307-317.

DE WAARD, D. \& Romey, W.D. 1969. Chemical and petrological trends in the anorthosite-charnockite series of the Snowy Mountains massif, Adirondack Highlands. American Mineralogist, 54, 529-538.

Demaiffe, D. \& Hertogen, J. 1981. Rare earth element geochemistry and strontium isotopic composition of a massif-type anorthositic-charnockitic body: the Hidra massif (Rogaland, SW Norway). Geochimica et Cosmochimica Acta, 45, 1545-1561.

Duchesne, J.C. \& Demaiffe, D. 1978. Trace elements and anorthosite genesis. Earth and Planetary Science Letters, 38, 249-272.

—, Wilmart, E., Demaiffe, D. \& Hertogen, J. 1989. Monzonorites from Rogaland (Southwest Norway): a series of rocks coeval but not comagmatic with massif-type anorthosites. Precambrian Research, 45, 111-128.

EMsLIE, R.F. 1980. Geology and petrology of the Harp Lake Complex, Central Labrador: An example of Elsonian magmatism. Bulletin of the Geological Survey of Canada, 293.

1985. Proterozoic anorthosite massif. In: ToвI, A. \& Touret, J.L.R. (eds) The Deep Proterozoic Crust in the North Atlantic provinces. NATO ASI Series C, 158. Reidel, Dordrecht, 39-60.

\& HeGNER, E. 1993. Reconnaissance isotopic geochemistry of anorthositemangerite-charnockite-granite (AMCG) complexes, Grenville Province, Canada. Chemical Geology, 106, 279-298.

Engel, A.E.J., Itson, S.P., Engel, C.G., Stickney, D.M. \& Cray, E.J. Jr. 1974. Crustal evolution and global tectonics: A petrogenetic view. Geological Society of America Bulletin, 85, 843-858.

Frith, R.A. \& Currie, K.L. 1976. A model for the origin of the Lac St Jean anorthosite massif. Canadian Journal of Earth Sciences, 13, 389-399.

Graham, I.J. 1987. Petrography and origin of metasedimentary xenoliths in lavas from Tongariro Volcanic Centre. New Zealand Journal of Geology and Geophysics, 30, 139-157.

Green, D.H. \& Ringwood, A.E. 1967. The genesis of basaltic magmas. Contributions to Mineralogy and Petrology, 15, 103-190.

Herz, N. 1969. Anorthosite belts, continental drift, and the anorthosite event. Science, 164, 944-947.

Hofmann, P.F. 1989. Speculations on Laurentia's first gigayear (2.0 to $1.0 \mathrm{Ga})$. Geology, 17, 135-138.

Menuge, J.F. 1988. The petrogenesis of massif anorthosites: a $\mathrm{Nd}$ and $\mathrm{Sr}$ isotopic investigation of the Proterozoic of Rogaland/Vest-Agder, SW Norway. Contributions to Mineralogy and Petrology, 98, 363-373.

Мiснот, P. 1964. Le magma plagioclasique. Geologische Rundschau, 54, 956976.

Morse, S.A. 1979. The influence of augite on plagioclase fractionation. Journal of Geology, 87, 202-208.

1982. A partisan review of Proterozoic anorthosites. American Mineralogist, 67, 1087-1100.

Philpotts, A.R. 1968. Parental magma of the anorthosite-mangerite suite. In: ISACHSEN, Y.W. (ed.) Origin of anorthosite and related rocks. New York State Museum and Science Service Memoir 18, 207-212.

1981. A model for the generation of massif-type anorthosites. Canadian Mineralogist, 19, 233-253.

Preston, R.J., Bell, B.R. \& Rogers, G. 1998. The Loch Scridain Xenolithic Sill Complex, Isle of Mull, Scotland: fractional crystallization, assimilation, magma-mixing and crustal anatexis in subvolcanic conduits. Journal of Petrology, 39, 519-550.

—, Dempster, T.J., Bell, B.R. \& Rogers, G. The petrology of mullite-bearing peraluminous xenoliths: implications for contamination processes in basaltic magmas. Journal of Petrology, in press.

RÄмÖ, O.T. \& HAAPALA, I. 1995. One hundred years of Rapakivi Granite. Mineralogy and Petrology, 52, 129-185.

TaYlor, S.R., Campbell, I.H., McCulloch, M.T. \& Mclennan, S.M. 1984. A lower crustal origin for massif-type anorthosites. Nature, 311, 372-374.

— \& McLennan, S.M. 1985. The continental crust: its composition and evolution. Blackwell, Oxford.

— \& 1996. The evolution of continental crust. Scientific American, 274, $60-65$. 
Thomas, H.H. 1922. On certain xenolithic Tertiary minor intrusions in the Island of Mull (Argyllshire). Quarterly Journal of the Geological Society of London, 78, 229-260.

Thompson, R.N. 1972. Melting behaviour of two Snake River lavas at pressures up to $35 \mathrm{~kb}$. Carnegie Institute of Washington Yearbook, 71, 406-410.

- Morrison, M.A., Dickin, A.P., Gibson, I.L. \& Harmon, R.S. 1986. Two contrasting styles of interaction between basic magmas and continental crust in the British Tertiary Volcanic Province. Journal of Geophysical Research, 91, 5985-5997.

van Bergen, M.J. \& Barton, M. 1984. Complex interaction of aluminous metasedimentary xenoliths and siliceous magma; an example from Mt. Amiata (Central Italy). Contributions to Mineralogy and Petrology, 86, 374-385.
VielzeuF, D. 1983. The spinel quartz associations in high grade xenoliths from Tallante (SE Spain) and their potential use in geothermometry and barometry. Contributions to Mineralogy and Petrology, 82, 301311.

WARK, D.A. \& StimaC, J.A. 1992. Origin of mantled (rapakivi) feldspars: Experimental evidence of a dissolution and diffusion-controlled mechanism. Contributions to Mineralogy and Petrology, 111, 345-361.

Wiebe, R.A. 1986. Lower crustal cumulate nodules in Proterozoic dikes of the Nain complex, Labrador: evidence for the origin of Proterozoic anorthosites. Journal of Petrology, 27, 1253-1275.

Xue, S. \& Morse, S.A. 1993. Geochemistry of the Nain massif anorthosite, Labrador: Magma diversity in five intrusions. Geochimica et Cosmochimica Acta, 57, 3925-3948.

Received 17 March 1998; revised typescript accepted 19 June 1998.

Scientific editing by Hugh Rollinson. 